\title{
WPEYW WIELOKROTNEGO PRZETWÓRSTWA POLIMERÓW NA PARAMETRY STANU TWORZYWA W FORMIE WTRYSKOWEJ
}

\begin{abstract}
Celem pracy było określenie zmian właściwości przetwórczych tworzywa polimerowego wynikających z jego wielokrotnego przetwórstwa. W badaniach wykorzystano polipropylen o nazwie handlowej Moplen HP500N. Na podstawie symulacji numerycznych procesu wtryskiwania wykonanych w systemie Autodesk Moldflow Insight 2013 dokonano analizy wpływu zmian właściwości przetwórczych tegoż tworzywa, lecz o różnej krotności przetwórstwa, na parametry jego stanu w gnieździe formy wtryskowej, w tym na: ciśnienie $p$, temperaturę tworzywa w gnieździe $T$, prędkość ścinania $\gamma$, naprężenia ścinające $\tau$. Uzyskane wyniki potwierdzają słuszność założenia, że ustawiane parametry technologiczne procesu przetwórstwa tworzyw polimerowych powinny uwzględniać zmianę ich właściwości przetwórczych związanych $\mathrm{z}$ ich wielokrotnym przetwórstwem. Istotnym parametrem jest wartość siły zwarcia formy.
\end{abstract}

Słowa kluczowe: wtryskiwanie, symulacje numeryczne, recykling tworzyw sztucznych

\section{Wprowadzenie}

Obecnie zagadnienie wielokrotnego przetwórstwa tworzyw sztucznych staje się niezwykle istotne, ponieważ coraz większą uwagę przywiązuje się do produkcji wyrobów przyjaznych środowisku. W produkcji różnego rodzaju wyrobów wykorzystuje się nie tylko granulat pierwotny, ale również materiał pochodzący z recyklingu. Recykling stanowi jedną z podstawowych metod ograniczania szkodliwego wpływu polimerów na środowisko naturalne. Istotą jego jest działanie zmierzające do minimalizowania ilości odpadów, z równoczesnym ograniczeniem popytu na surowce i energię, poprzez włączenie do powtórnego obiegu odzyskanych surowców bądź materiałów [1]. Dla wielu rodzajów tworzyw sztucznych korzystnym dla środowiska i ekonomicznie użyteczniejszym rodzajem utylizacji odpadów jest ich recykling materiałowy, którego produkty (tzw. recyklaty, reglanulaty) mogą stanowić z jednej strony surowce samodzielne (do wytwarzania nowych wyrobów), z drugiej zaś surowce uzupełniające do tworzywa wyjściowego. Należy pamiętać, że o jakości wyrobów decyduje ja- 
kość recyklatu użytego do ich wytwarzania [2]. Istotnym zagadnieniem z punktu widzenia możliwości wielokrotnego wykorzystania tworzyw sztucznych jest więc wpływ przetwórstwa na ich właściwości.

Podczas procesów granulowania, aglomerowania czy rozdrabniania, a także przetwórstwa w stanie plastyczno-płynnym polimery są poddawane obciążeniom mechanicznym oraz termicznym. Prowadzi to do procesów utleniania i degradacji, które to są przyczyną zmniejszania ciężaru cząsteczkowego i pogarszania właściwości nie tylko fizykomechanicznych, ale również przetwórczych. Należy dodać, że recykling materiałowy jest ekonomicznie opłacalny tylko w przypadku, gdy właściwie przygotowany recyklat jest tworzywem konstrukcyjnym przeznaczonym do rozwiązań typu high-tech, co stanowi jego poważne ograniczenie [3].

W celu zapewnienia produkcji wysokiej jakości wyrobów z wykorzystaniem odpadów produkcyjnych niezbędne staje się prowadzenie badań umożliwiających sprawdzenie zarówno wpływu wielokrotnego przetwórstwa polimerów na właściwości przetwórcze tworzyw, jak i skutków tych zmian na parametry stanu tworzywa w gnieździe formy wtryskowej, a więc również na parametry technologiczne. Znajomość tych właściwości pozwala precyzyjnie przeprowadzać symulacje numeryczne procesów technologicznych wykorzystujących recyklat materiałowy, uwzględniając rzeczywiste właściwości przetwarzanych tworzyw polimerowych.

Badania wpływu krotności przetwórstwa na właściwości polimerów były podejmowane wielokrotnie, m.in. w pracy [4]. Uzyskane wyniki pokazują, że wraz z krotnością przetwórstwa zmieniają się właściwości mechaniczne tworzyw polimerowych. Wielokrotne badania, również właściwości przetwórczych [5, 6], uwzględniające podstawowe wskaźniki przetwórcze (jak np. MFR) potwierdzają zmiany we właściwościach przetwórczych polimerów. Badania takie to głównie badania jakościowe. Uzyskane wyniki nie pozwalają więc wykonać szczegółowych analiz przebiegu procesu przetwórstwa.

Podjęcie w niniejszej pracy takiej tematyki uzasadnia konieczność poznania kompleksowych właściwości przetwórczych wielokrotnie przetwarzanych tworzyw. Zmiana charakterystyki płynięcia uplastycznionego tworzywa $\mathrm{w}$ formie skutkuje zmianą parametrów stanu tworzywa w gnieździe formującym. Może to wpłynąć np. na dobór maszyn lub urządzeń do przetwórstwa oraz korektę nastaw parametrów technologicznych.

\section{Cel, zakres oraz metodyka badań}

Celem przeprowadzonych badań było zbadanie zmian właściwości tworzywa wraz z krotnością przetwórstwa oraz określenie, z wykorzystaniem symulacji numerycznych procesu wtryskiwania, ich skutków na wybrane parametry stanu tworzywa w formie podczas kolejnych krotności przetwórstwa. W badaniach 
wykorzystano polipropylen o nazwie handlowej Moplen HP500N. Granulat pierwotny poddano wielokrotnemu przetwarzaniu. Po każdym cyklu przetwórstwa wyroby rozdrabniano, a z przemiału wytwarzano kolejne. Przemiał badano pod kątem właściwości reologicznych za pomocą plastometru, a następnie reometru kapilarnego. Otrzymane wyniki badań aproksymowano za pomocą znanych modeli reologicznych, które następnie zastosowano w symulacjach numerycznych procesu wtryskiwania przyjętego modelu wypraski. Kształt oraz wymiary gabarytowe modelu wypraski wykorzystywanego w symulacjach numerycznych zapewnił możliwość obserwacji zmian, nawet tych niewielkich, parametrów stanu tworzywa w formie wtryskowej.

$\mathrm{Z}$ granulatu pierwotnego wytwarzano próbki w kształcie wiosełek. Tworzywo było wtryskiwane z użyciem formy dwugniazdowej. Recyklat do badań uzyskiwano z zastosowaniem stałego schematu czynności. Próbki z każdej serii rozdrabniano za pomocą młynka do tworzyw polimerowych. Część przemiału poddawano analizie właściwości reologicznych, a pozostały przemiał w danym cyklu ponownie poddawano przetwórstwu na wtryskarce. Cykl ten powtarzano do momentu uzyskania przemiału o pięciokrotnym stopniu przetwórstwa (tab. 1.).

Po każdym stopniu przetwórstwa granulat pierwotny oraz przemiał poddano badaniom właściwości przetwórczych na plastometrze Ceast Melt Flow oraz reometrze kapilarnym Ceast SmartRHEO 2000. Za pomocą plastometru wyznaczono zgodnie z danymi [7] wartości masowego wskaźnika szybkości płynięcia (MFR). Warunki, w jakich zostały przeprowadzone badania MFR przedstawia tab. 2. Analiza wyników wartości wskaźnika MFR wyznaczonego po kolejnych cyklach przetwórstwa (tab. 3.) pozwala zaobserwować jego zmianę, co uzasadniało przeprowadzenie dodatkowych badań reologicznych za pomocą reometru. Posługiwanie się tylko wartością wskaźnika MFR ma charakter jedynie poglądowy. Aby dokładnie ocenić zmianę lepkości polimeru, należy sporządzić charakterystykę reologiczną. Reometr kapilarny wykorzystano w celu wyznaczenia eksperymentalnej krzywej lepkości w szerokim zakresie szybkości ścinania.

Tabela 1. Wykaz oznaczeń recyklatu stosowanych podczas badań Table 1. List of designations used in the tests

\begin{tabular}{|l|c|}
\hline \multicolumn{1}{|c|}{ Rodzaj recyklatu } & Oznaczenie \\
\hline Granulat pierwotny Moplen HP500N & $\mathrm{R} 0$ \\
\hline Granulat przetworzony jednokrotnie & $\mathrm{R} 1$ \\
\hline Granulat przetworzony dwukrotnie & $\mathrm{R} 2$ \\
\hline Granulat przetworzony trzykrotnie & $\mathrm{R} 3$ \\
\hline Granulat przetworzony czterokrotnie & $\mathrm{R} 4$ \\
\hline Granulat przetworzony pięciokrotnie & $\mathrm{R} 5$ \\
\hline
\end{tabular}


Tabela 2. Warunki badań prowadzonych z użyciem plastometru Ceast Melt Flow

Table 2. Terms of studies carried out with Ceast

Melt Flow plastometer

\begin{tabular}{|l|c|}
\hline Temperatura [ $\left.{ }^{\mathbf{0}} \mathbf{C}\right]$ & 200 \\
\hline Nagrzewanie bez obciążenia [s] & 300 \\
\hline Obciążenie [N] & 21,6 \\
\hline Długość pomiarowa [mm] & 30 \\
\hline Odstęp czasu odcinania [s] & 10 \\
\hline
\end{tabular}

Tabela 3. Wartości MFR $\left(200^{\circ} \mathrm{C} ; 21,6 \mathrm{~N}\right)$ dla tworzywa pierwotnego (R0) oraz serii R1-R5

Table 3. MFR $\left(200^{\circ} \mathrm{C} ; 2,16 \mathrm{~N}\right)$ values for the virgin Moplen HP500N (R0) and for a series of R1-R5 reprocessed polymer

\begin{tabular}{|c|c|c|c|c|c|c|}
\hline Stopień przetwórstwa & R0 & R1 & R2 & R3 & R4 & R5 \\
\hline MFR $[\mathrm{g} / 10 \mathrm{~min}]$ & 5,748 & 8,705 & 9,760 & 9,516 & 9,992 & 10,755 \\
\hline
\end{tabular}

Wartość lepkości tworzywa obliczano z prawa Newtona:

$$
\eta=\frac{\tau}{\gamma}
$$

Właściwości reologiczne granulatu pierwotnego badano, wykorzystując dwie dysze pomiarowe o $L / D=10: 1$ oraz $L / D=20: 1$, w temperaturze $220^{\circ} \mathrm{C}$ i $230^{\circ} \mathrm{C}$. Wyznaczono wartość poprawki Bagleya. Poprawka ta koryguje wzrost ciśnienia tworzywa przepływającego przez kapilarę, wynikający ze wzrostu długości kapilary. Są to tzw. straty wlotowe. Pominięcie strat wlotowych powoduje zawyżenie doświadczalnie wyznaczonego naprężenia ścinającego w stosunku do jego wartości rzeczywistej [8]. Uwzględniając tę poprawkę, wartości rzeczywiste naprężenia ścinającego $\tau$ oblicza się z zależności:

$$
\tau=\frac{p}{4\left[\left(\frac{L}{D}\right)+\left(\frac{L}{D}\right)_{c}\right]}
$$

gdzie: $p$-ciśnienie,

$(L / D)_{c}$ - stosunek wymiarów dyszy, przy którym $p=0$.

Stwierdzono, że wpływ poprawki Bagleya jest nieistotny, w związku z czym kolejne recyklaty badano w temperaturze $200^{\circ} \mathrm{C}$, wykorzystując dyszę o $L / D=20: 1$. W obliczeniach uwzględniono również poprawkę Rabinowitscha 
korygującą szybkość ścinania. Wartość rzeczywistej szybkości ścinania wyznaczono dla $L / D=20: 1$ oraz $L / D=10: 1$ z zależności:

$$
\gamma=\frac{\gamma_{p}}{4} \cdot\left(3+\frac{d \log \gamma_{p}}{d \log \tau}\right)
$$

gdzie: $\gamma_{p}$ - pozorna szybkość ścinania,

$\tau$ - naprężenia ścinające.

Charakterystyki reologiczne otrzymane eksperymentalnie dla badanego tworzywa, uzyskane w temperaturze $200^{\circ} \mathrm{C}$, w zależności od krotności przetwórstwa przedstawiono na rys. 1. Ogólnie wiadomo, że szybkość ścinania w przypadku pomiarów prowadzonych w rzeczywistych warunkach wtryskiwania mieści się w zakresie $10^{4}-10^{6} \mathrm{~s}^{-1}$ [9]. Wykonane za pomocą reometru pomiary dostarczają informacji na temat zachowania się polimeru tylko w zakresie szybkości ścinania $10^{2}-10^{4} \mathrm{~s}^{-1}$ (rys. 1.). Aby uzyskać dane w szerszym zakresie, otrzymane doświadczalnie wyniki aproksymuje się za pomocą znanych modeli teoretycznych. W dalszej części pracy do aproksymacji zastosowano 7-parametrowy model Crossa-WLF. Na podstawie danych eksperymentalnych wyznaczono współczynniki dla równania charakteryzującego ten model matematyczny.

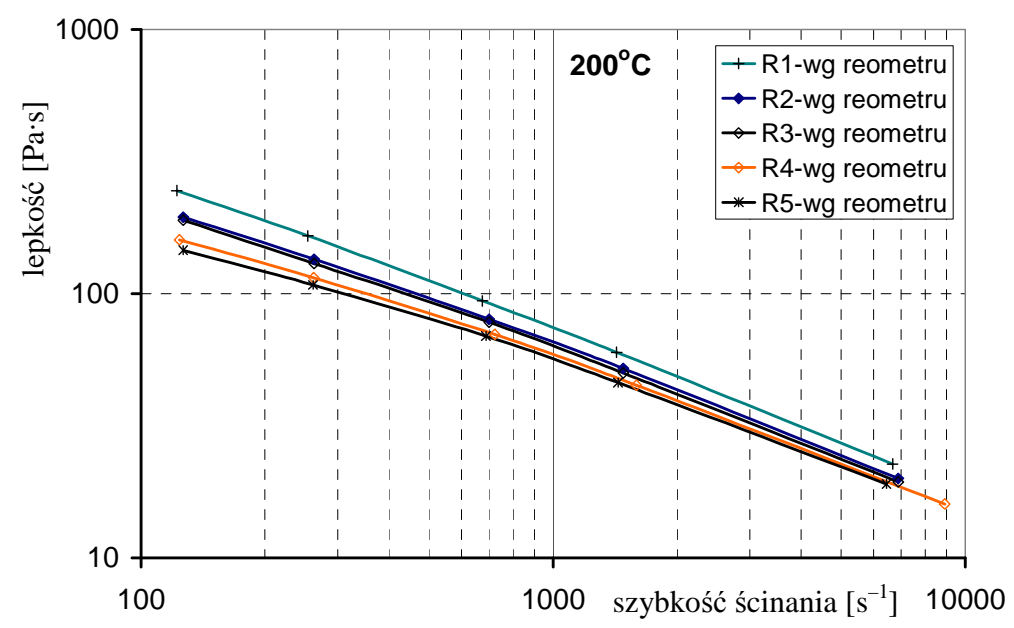

Rys. 1. Zależność lepkości od prędkości ścinania w temperaturze $200^{\circ} \mathrm{C}$ dla tworzywa Moplen HP500N o różnej krotności przetwórstwa wyznaczona eksperymentalnie

Fig. 1. The experimentally predicted viscosity-shear rate curves at $200^{\circ} \mathrm{C}$ for Moplen HP500N polymer at different reprocessing phases 


\section{Wyznaczenie parametrów modelu reologicznego Crossa-WLF}

Model reologiczny Crossa-WLF jest uznawany za model zapewniający wysoką dokładność aproksymacji danych eksperymentalnych. W komercyjnym pakiecie oprogramowania Autodesk Moldflow Insight 7-parametrowy model od lat jest podstawowym modelem matematycznym opisującym właściwości reologiczne polimerów. Pozwala on obliczać wartości lepkości w dowolnej temperaturze. W modelu tym lepkość jest funkcją temperatury, ciśnienia i szybkości ścinania. Niestety podstawowym problemem jego wykorzystania jest trudność związana z określeniem wartości parametrów zależnych. W modelu tym lepkość polimeru opisuje równanie Crossa:

$$
\eta(\gamma, T, p)=\frac{\eta_{0}(T, p)}{1+\left(\frac{\eta_{0} \cdot \gamma}{\tau^{*}}\right)^{1-n}}
$$

Lepkość zerowa $\eta_{0}$ jest obliczana $\mathrm{z}$ równań Williama-Landela-Ferry'ego (WLF):

$$
\begin{aligned}
& \eta_{0}(T, p)=D_{1} \cdot \exp \left[-\frac{A_{1} \cdot\left(T-T_{g}\right)}{A_{2}+\left(T-T_{g}\right)}\right] \\
& T^{*}=D_{2}+D_{3} \cdot p \\
& A_{2}=\tilde{A}_{2}+D_{3} \cdot p \\
& D_{2}=T_{g} \\
& D_{3}=\frac{\partial T_{g}}{\partial p}
\end{aligned}
$$

gdzie: $p$ - ciśnienie,

$n, \tau^{*}$ - parametry zależne modelu ( $\tau^{*}$ - naprężenie styczne, przy którym plastyczno-płynne tworzywo zaczyna wykazywać właściwości płynu rozrzedzonego ścinaniem, $n$ - wykładnik płynięcia),

$T$ - temperatura,

$T^{*}$ - temperatura zeszklenia polimeru, 
$D_{1}$ - parametr zależny modelu przedstawiający lepkość polimeru dla szybkości ścinania równej $0 \mathrm{w}$ temperaturze zeszklenia i przy ciśnieniu atmosferycznym,

$D_{2}$ - stała w modelu reprezentująca temperaturę zeszklenia polimeru przy ciśnieniu atmosferycznym,

$D_{3}$ - stała modelu określająca zmianę temperatury zeszklenia w zależności od ciśnienia (dla ciśnienia atmosferycznego $D_{3}=0$ ),

$A_{1}$ - parametr zależny modelu przedstawiający czułość zmian lepkości polimeru na temperaturę przy szybkości ścinania równej 0 ,

$\tilde{A}_{2}$ - stała modelu, która zależy od gatunku rozpatrywanego polimeru $[10,11]$.

Parametry modelu Crossa, które zależą tylko od gatunku polimeru, określono na podstawie badań granulatu pierwotnego za pomocą różnicowego kalorymetru skaningowego DSC Q200 firmy TA Instruments oraz bazy danych tworzyw polimerowych zintegrowanej z programem Autodesk Moldflow MPI 2013. Parametry te mają wartość: $\tilde{A}_{2}=51,6 \mathrm{~K}, T_{g}=263,15 \mathrm{~K}, D_{3}=0 \mathrm{~K} / \mathrm{Pa}$. Do obliczeń parametrów zależnych w równaniu Crossa-WLF wykorzystano program komercyjny DataFit 9 firmy Oakland Engineering. Otrzymane w wyniku obliczeń parametry równania Crossa-WLF dla granulatu pierwotnego oraz tworzywa po kolejnych cyklach przetwórstwa zamieszczono w tab. 4. Obliczone współczynniki pozwalają określić właściwości reologiczne tworzywa po kolejnych stopniach przetwórstwa w szerokim zakresie szybkości ścinania (rys. 2.). Umożliwia to przeprowadzenie symulacji numerycznych procesu wtryskiwania pozwalających dokonać analizy wpływu krotności przetwórstwa na parametry stanu tworzywa w formie wtryskowej.

Tabela 4. Wybrane wartości parametrów modelu Crossa-WLF dla granulatu pierwotnego (R0) oraz recyklatów R1-R5

Table 4. Selected parameters of the Cross-WLF equation for virgin (R0) and (R1-R5) reprocessed polymers

\begin{tabular}{|l|c|c|c|c|c|c|}
\hline \multicolumn{1}{r|}{$\begin{array}{r}\text { Stopień } \\
\text { przetwórstwa }\end{array}$} & $\mathbf{R 0}$ & $\mathbf{R 1}$ & $\mathbf{R 2}$ & $\mathbf{R 3}$ & $\mathbf{R 4}$ & $\mathbf{R 5}$ \\
$\begin{array}{l}\text { Parametr } \\
\text { modelu Crossa-WLF }\end{array}$ & & & & & & \\
\hline $\boldsymbol{n}[-]$ & 0,3452 & 0,3577 & 0,3598 & 0,3546 & 0,3597 & 0,3612 \\
\hline$\tau^{*}[\mathbf{P a}]$ & 18759,4 & 19455,6 & 19461,7 & 21455,7 & 22569,6 & 25569,6 \\
\hline $\boldsymbol{D}_{\mathbf{1}}[\mathbf{G P a}]$ & 787,8 & 2198 & 1813 & 1299 & 2026 & 2425 \\
\hline $\boldsymbol{D}_{\mathbf{2}}[\mathbf{K}]$ & 263,15 & 263,5 & 263,15 & 263,15 & 263,15 & 263,5 \\
\hline $\boldsymbol{D}_{\mathbf{3}}[\mathbf{K} / \mathbf{P a}]$ & 0 & 0 & 0 & 0 & 0 & 0 \\
\hline $\boldsymbol{A}_{\mathbf{1}}[-]$ & 25,347 & 26,91 & 26,99 & 26,81 & 27,72 & 28,21 \\
\hline $\boldsymbol{A}_{\mathbf{2}}[\mathbf{K}]$ & 51,6 & 51,6 & 51,6 & 51,6 & 51,6 & 51,6 \\
\hline
\end{tabular}




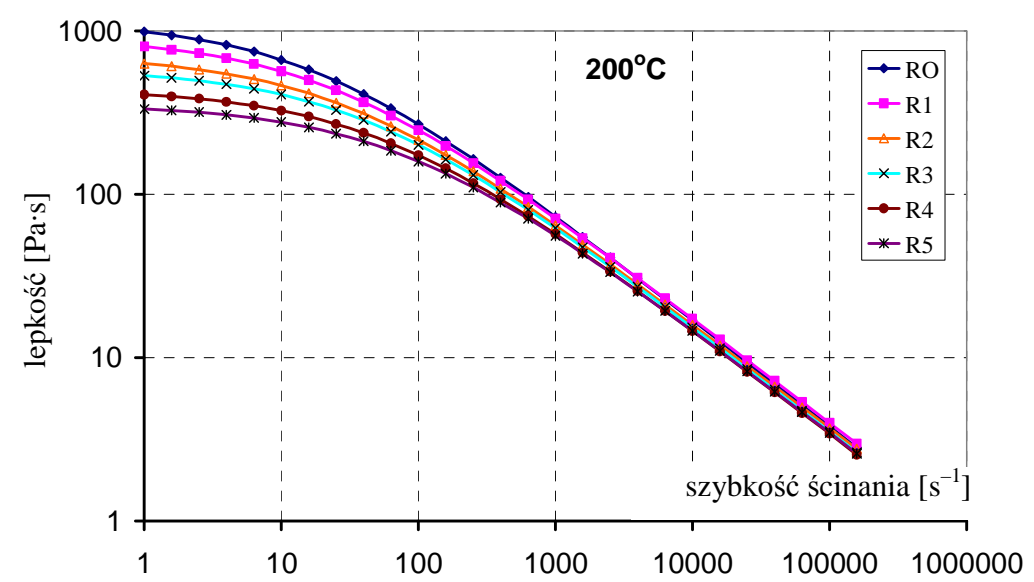

Rys. 2. Zależność lepkości od prędkości ścinania w temperaturze $200^{\circ} \mathrm{C}$ dla tworzywa Moplen HP500N o różnej krotności przetwórstwa wg 7-parametrowego modelu Crossa-WLF

Fig. 2. The viscosity - shear rate curves at $200^{\circ} \mathrm{C}$ for Moplen HP500N polymer at different reprocessing phases acc. to 7-parameters Cross-WLF model

\section{Symulacje numeryczne}

Symulacje numeryczne procesu wtryskiwania wykonano w systemie Autodesk Moldflow Insight 2013. Analizowany model wypraski to tylna pokrywa monitora komputerowego LCD 21'. Wymiary gabarytowe wypraski to: $496 \mathrm{x}$ x 326 x $50 \mathrm{~mm}$, przy maksymalnej grubości ściany równej $3 \mathrm{~mm}$. Model dyskretyzowano w technologii Dual Domain za pomocą 122326 elementów skończonych (ES) typu trójkątnego (rys. 3.). Dla każdej krotności przetwórstwa zostały przeprowadzone symulacje $\mathrm{z}$ zachowaniem jednakowych parametrów przetwórczych. Założono temperaturę formy $35^{\circ} \mathrm{C}$, temperaturę uplastycznionego tworzywa $235^{\circ} \mathrm{C}$. Wypełnienie gniazda formy ustalono w czasie równym $2 \mathrm{~s}$, fazę docisku na poziomie $80 \%$ ciśnienia wtrysku i w czasie $30 \mathrm{~s}$, a czas chłodzenia zadano na $20 \mathrm{~s}$.

Podczas analizy wyników uzyskanych z symulacji numerycznych najwięcej uwagi zwrócono na takie reprezentatywne parametry, jak: ciśnienie panujące w gnieździe formy wtryskowej, średnia ważona temperatura na przekroju wypraski, prędkość ścinania, naprężenia ścinające. Przebieg zmian ciśnienia w gnieździe formującym dla wybranych, charakterystycznych węzłów siatki elementów skończonych (np. N305865 - początek tulei wtryskowej, N292984 


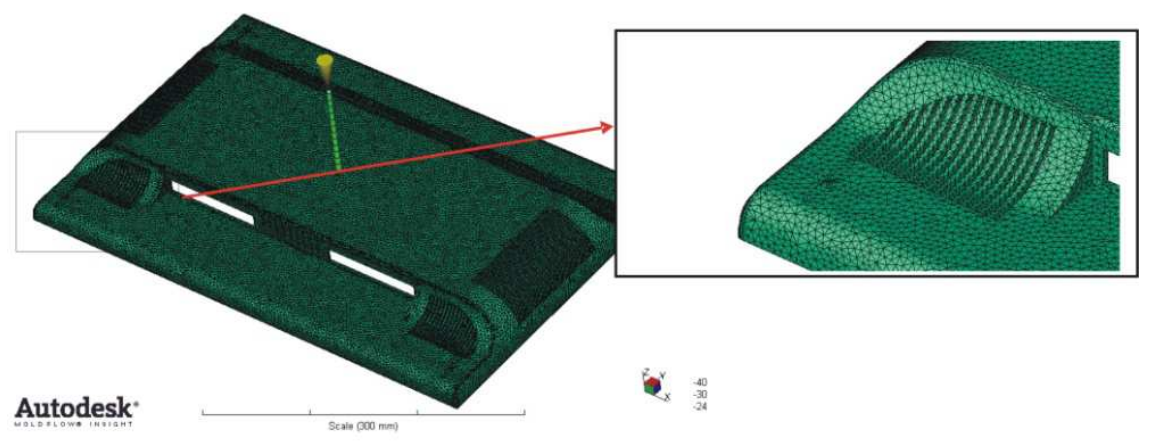

Rys. 3. Model badanej wypraski z wygenerowaną siatką elementów skończonych i układem wlewowym

Fig. 3. Moulded piece finite elements (FE) model with runner system geometry

a)

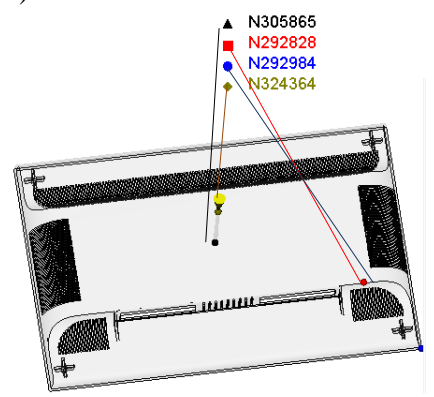

c)

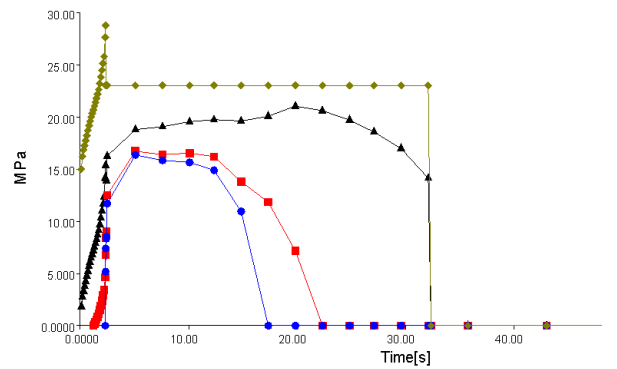

b)

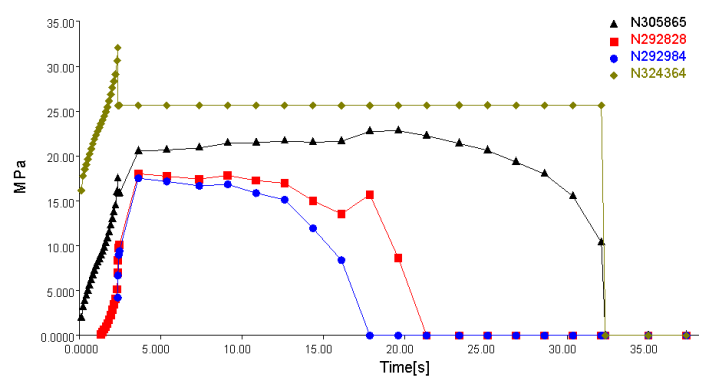

d)

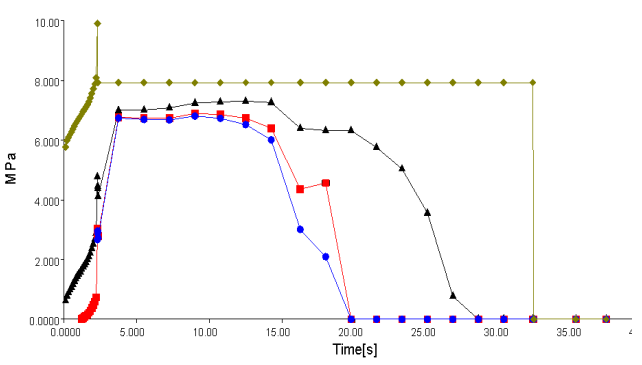

Rys. 4. Zależność zmian ciśnienia w gnieździe formy dla symulacji fazy wypełnienia gniazda: a) lokalizacja wybranych węzłów siatki ES, b) dla granulatu pierwotnego (R0), c) dla recyklatu (R3) przetworzonego trzykrotnie, d) dla recyklatu (R5) przetworzonego pięciokrotnie

Fig. 4. The pressure dependence in the mold cavity during filling phase for chosen FE nodes (a): b) for virgin polymer (R0), c) for reprocessed (R3) three times polymer, d) for reprocessed (R5) five times polymer 
- koniec przekątnej pokrywy odpowiadający maksymalnej drodze płynięcia tworzywa) przedstawiono dla kolejnych krotności przetwórstwa (rys. 4.). Analiza tych wyników potwierdza zmianę profilu i wartości ciśnienia w gnieździe formy wraz z krotnością przetwórstwa tworzywa.

Zaobserwowano również pewne zmiany wartości naprężeń ścinających. Wartość tych naprężeń zmniejszyła się dla pięciokrotnie przetwarzanego tworzywa niemal o $100 \%$ (rys. 5.). Potwierdza to znaczny wpływ krotności przetwórstwa na zmianę parametrów stanu tworzywa w formie. Rysunki 6-9. zawierają zestawienie wyników symulacji komputerowych dotyczących stanu two-

a)

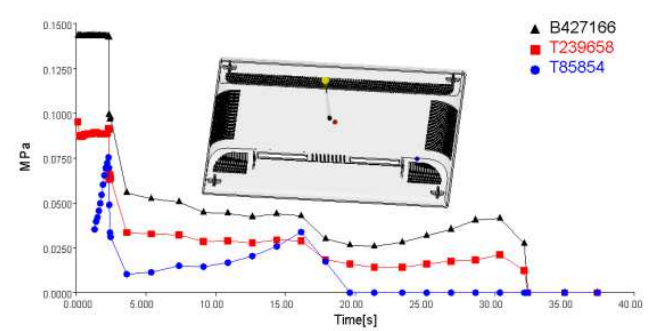

b)

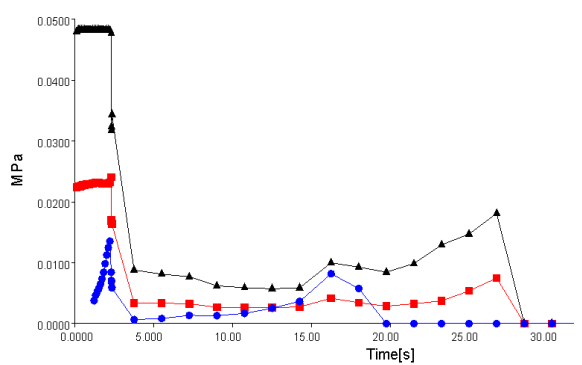

Rys. 5. Naprężenia ścinające dla charakterystycznych obszarów gniazda podczas fazy wypełniania: a) dla granulatu pierwotnego (R0), b) dla recyklatu (R5) przetworzonego pięciokrotnie

Fig. 5. Shear stress versus time for chosen areas of the moulded piece during filling phase for: a) virgin polymer (R0), b) reprocessed (R5) five times polymer

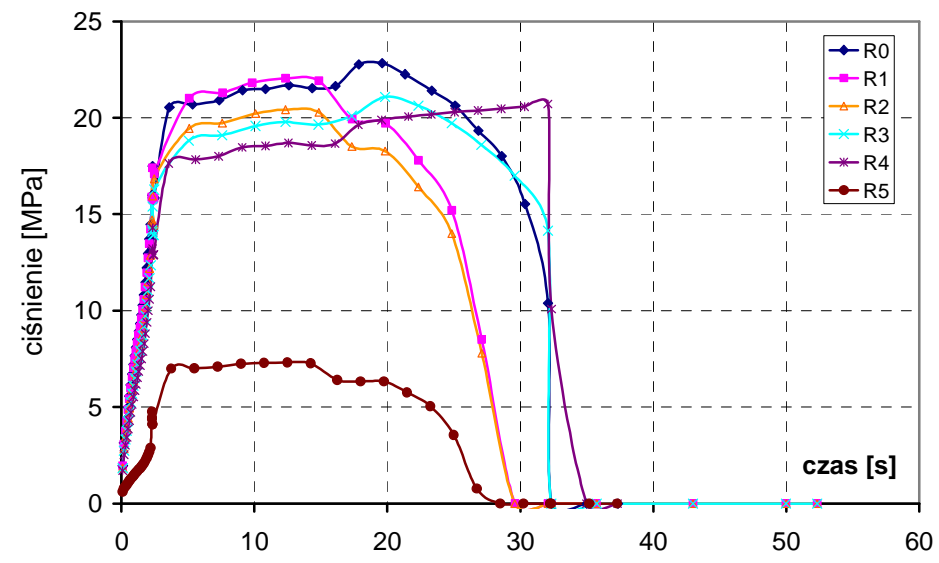

Rys. 6. Zależność zmian ciśnienia od czasu obliczonych na końcu układu wlewowego dla granulatu pierwotnego i recyklatów o różnym stopniu przetwórstwa

Fig. 6. Pressure versus time calculated at the end of the runner system for the virgin and reprocessed polymer 


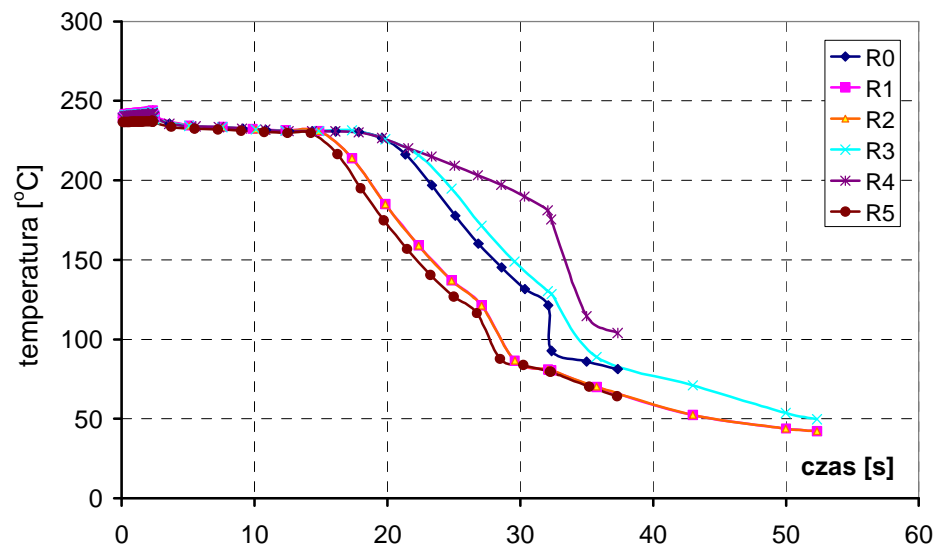

Rys. 7. Zależność zmian średniej ważonej temperatury wypraski od czasu dla granulatu pierwotnego i recyklatów o różnym stopniu przetwórstwa

Fig. 7. Bulk temperature calculated for the virgin and reprocessed polymer

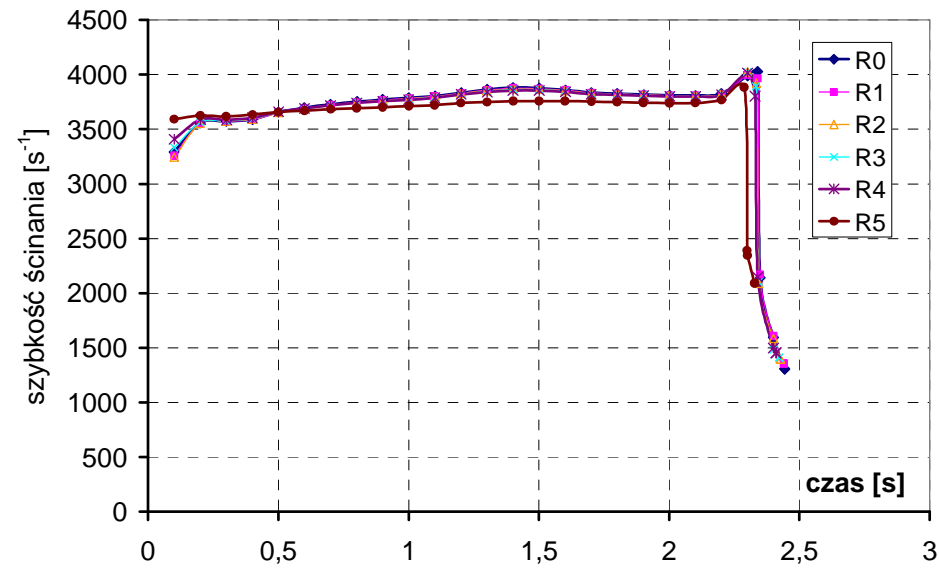

Rys. 8. Zależność zmian szybkości ścinania od czasu obliczonych na końcu układu wlewowego dla granulatu pierwotnego i recyklatów o różnym stopniu przetwórstwa

Fig. 8. Shear rate versus time calculated at the end of the runner system for the virgin and reprocessed polymer 


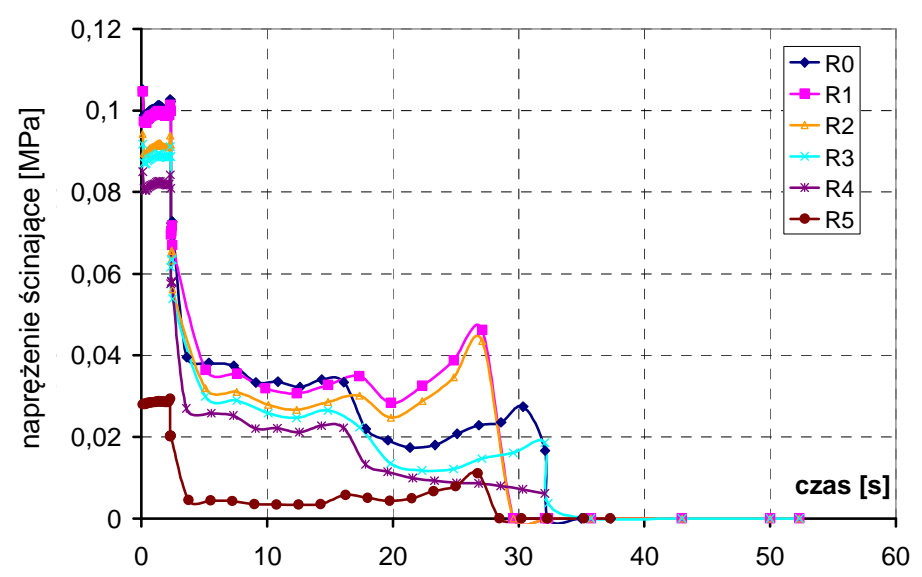

Rys. 9. Zależność zmian naprężeń ścinających od czasu obliczonych na końcu układu wlewowego dla granulatu pierwotnego i recyklatów o różnym stopniu przetwórstwa

Fig. 9. Shear stress versus time calculated at the end of the runner system for the virgin and reprocessed polymer

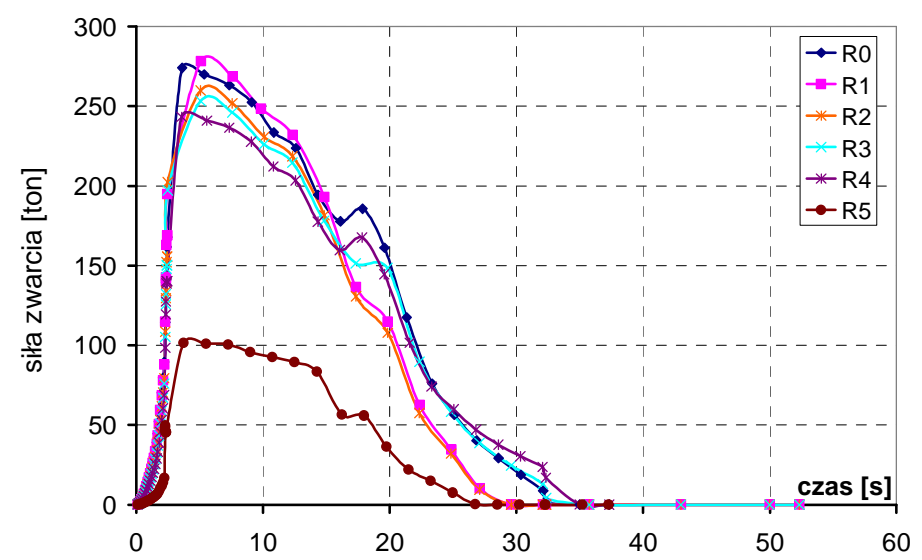

Rys. 10. Zmiany siły zwarcia formy w czasie dla różnych krotności przetwórstwa tworzywa

Fig. 10. Clamping force for virgin and reprocessed polymer 
rzywa w gnieździe formy wtryskowej dla charakterystycznego węzła N309391 (węzeł końcowy układu wlewowego) i elementu T383712, odpowiadającemu temu obszarowi w odniesieniu do wszystkich analizowanych krotności przetwórstwa tworzywa. Zmiana parametrów tworzywa w gnieździe formy skutkuje przede wszystkim zmianą wartości siły zwarcia formy. Jej wartość ulega znacznym zmianom (do 100\%, rys. 10.). W niektórych procesach technologicznych tak duża różnica $w$ wartości siły maksymalnej prowadzi do zmiany maszyny do przetwórstwa, umożliwiając pożądaną redukcję kosztów produkcji.

\section{Wnioski}

Na podstawie analizy wyników badań stwierdzono, że wraz z krotnością przetwórstwa zmniejsza się lepkość, co ma związek z degradacją mechaniczną i termiczną łańcuchów polimerowych podczas procesu przetwórstwa. Potwierdzają to przeprowadzone badania reometryczne, wykazujące zmianę charakterystyki przetwórczej badanego polimeru. Na podstawie wykonanych symulacji numerycznych stwierdzono:

- symulacje numeryczne pokazują spadek ciśnienia w gnieździe formy; w skrajnym przypadku wartość ciśnienia uległa zmniejszeniu o ponad $100 \%$ (seria R5) w porównaniu z wartością ciśnienia obliczoną dla granulatu pierwotnego,

- rozkład temperatury na przekroju wypraski dla wszystkich krotności przetwórstwa jest zbliżony przez pierwsze $15 \mathrm{~s}$; po tym czasie pojawiają się jednak znaczne odchylenia od profilu uzyskanego dla granulatu pierwotnego,

- prędkość ścinania w analizowanych przypadkach niemal się nie zmienia,

- w niemalże wszystkich przypadkach symulacji wartości naprężeń ścinających są do siebie zbliżone, a różnica wyników oscyluje w granicach wynoszących ok. 20\%; znacznie większą rozbieżność stwierdzono dla recyklatu R5.

Reasumując, należy stwierdzić, że wyniki uzyskane z badań oraz symulacji są zbieżne ze spodziewanymi trendami, na które wskazywały zmiany wskaźnika szybkości płynięcia MFR. Wśród analizowanych czynników w znaczący sposób zmianie ulega ciśnienie $w$ gnieździe formy i naprężenie ścinające. Krotność przetwórstwa wpływa więc na właściwości reologiczne tworzywa (różnice w przebiegu krzywych lepkości). W przypadku wykonywania dokładnych obliczeń należy więc (o ile jest to możliwe) wykonywać badania reometryczne recyklatu celem ustalenia jego rzeczywistej charakterystyki reologicznej. Posługiwanie się charakterystykami przetwórczymi wyznaczonymi dla granulatu pierwotnego podczas przetwarzania recyklatu może spowodować, w zależności od krotności przetwórstwa tworzywa, istotne błędy obliczeniowe. 
Oprócz charakterystyki reologicznej tworzywa polimerowego zmianom niewątpliwie może ulegać również charakterystyka termodynamiczna typu: ciśnienie - objętość właściwa - temperatura $(p-v$ - T). Zakres przedstawionej pracy nie obejmuje analizy zmian objętości właściwej tworzywa polimerowego, która w istotny sposób może wpływać na przebieg fazy docisku w procesie wtryskiwania.

\section{Literatura}

[1] Merkisz-Guranowska A.: Aspekty rozwoju recyklingu w Polsce, Instytut Technologii Eksploatacji w Radomiu - Państwowy Instytut Badawczy, Poznań-Radom 2005.

[2] Błędzki A. (red.): Recykling materiałów polimerowych, WNT, Warszawa 1997.

[3] Kijeński J., Błędzki A., Jeziórska R.: Odzysk i recykling materiałów polimerowych, PWN, Warszawa 2011.

[4] Samujło B., Kowalska B., Rudawska A.: Wybrane właściwości mechaniczne polipropylenu wielokrotnie przetwarzanego, Zeszyty Naukowe Politechniki Rzeszowskiej, Chemia, 20, Rzeszów 2009, 127-130.

[5] Malinowski R., Szach A.: Wielokrotne przetwarzanie biodegradowalnych tworzyw polimerowych, Zeszyty Naukowe Politechniki Rzeszowskiej, Chemia, 20, Rzeszów 2009, 91-94.

[6] Pielichowski J., Prociak A., Michałowski S., Bogdał D.: Możliwości wykorzystania odpadów wybranych polimerów w produkcji spienionych tworzyw poliuretanowych, Polimery, 55 (2010) 10, 757-763.

[7] PN-EN ISO 1133: Oznaczanie masowego wskaźnika szybkości płynięcia (MFR) i objętościowego wskaźnika szybkości płynięcia (MVR) tworzyw termoplastycznych.

[8] Sikora R.: Podstawy przetwórstwa tworzyw polimerowych, Wydawnictwo Uczelniane Politechniki Lubelskiej, Lublin 1992.

[9] Kloziński A., Sterzyński T.: Ocena poprawek w pomiarach reometrycznych polietylenu, Polimery, 52 (2007), 583-590.

[10] Peydro M.A., Juarez D., Crespo J.E., Parres F.: Study of rheological behavior of reprocessing polyamide 6, Annals of the Oradea University, 10 (20) (2011), 4.1094.116.

[11] Frącz W.: Przetwórstwo tworzyw polimerowych. Laboratorium, Oficyna Wydawnicza Politechniki Rzeszowskiej, Rzeszów 2011.

Badania eksperymentalne zostaty zrealizowane $z$ wykorzystaniem aparatury zakupionej w ramach projektów UDA-RPPK.01.03.00-18-003/10 oraz POPW 01.03.00-18012/09-00 wspótfinansowanych ze środków UE the European Union from the European Regional Development Fund within Regional Operational Programme for the Podkarpackie Region for the years 2007-2013. 


\section{THE INFLUENCE OF POLYMERS MULTIPLE PROCESSING} ON PLASTIC PARAMETERS IN THE INJECTION MOULD

Abstract

The aim of this study was to determine the changes in the rheological properties of the polymers resulting from their multiple re-processing. In the study the polypropylene with trade name: Moplen HP500N, was used. Based on numerical simulation of the injection molding process, made by means commercial code Autodesk Moldflow Insight 2013, there were performed analysis of the influence of the polymer processing properties with different re-processing times on the parameters of plastics in the mould, including: pressure $\mathrm{p}$, the bulk temperature $T$, shear rate $\gamma$ and shear stress $\tau$. Numerical simulation results confirm the validity of the assumption that the technological parameters of the polymer processing should consider changing rheological properties of plastic, related to their multiple reprocessing. An important parameter is the value of the mould clamping force.

Keywords: injection moulding, numerical simulations, recycling of plastics

DOI: $10.7862 / \mathrm{rm} .2012 .2$ 